\title{
EDUCATION
}

\section{Teaching of the assessment of head and brain injury in UK dental schools - The Headway Survey}

\author{
H. R. Chapman, ${ }^{1}$ G. P. Nickson ${ }^{2}$ and A. L. M. Curran ${ }^{3}$
}

\section{"It would be important for dentists to be in a position to accurately assess and refer or re-refer patients with suspected deterioration and signs of acute brain injury."}

\footnotetext{
$1^{*}$ Registered Specialist in Paediatric Dentistry, 8 Millais Court, Manor Fields, Horsham, West Sussex, RH13 6SJ; 2Formerly Policy and Campaigns Manager, Headway, 4 King Edward Court, King Edward Street, Nottingham, NG1 1EW; ${ }^{3}$ Consultant Paediatric Neurologist, Alder Hey Children's Hospital, Eaton Road, Liverpool L12 2AP

*Correspondence to: Dr Helen Chapman Email:helen.chapman@tesco.net
}

Under the auspices of Headway - the brain injury association, the charity supplies information on head/brain injury and runs a telephone advice line: (0115 9240800$)$. Questionnaires regarding the undergraduate teaching related to head/brain injuries were sent to, and returned by, all 12 UK dental schools. The replies suggest that undergraduate teaching of this subject is patchy and inadequately prepares dentists to recognise and cope with patients who may have had head, and consequently brain, injuries. It is recommended that dental schools review their teaching of this subject and ensure that it is consistent with the current guidelines issued by the National Institute of Clinical Excellence (NICE) on the recognition of head injury and that the findings are brought to the attention of the General Dental Council in the context of the GDC's The first five years report.

\section{INTRODUCTION}

The registered charity, Headway - the brain injury association, was interested in the level of training received by dentists in the recognition of head injury. This is of increased importance as the increased wearing of protective equipment such as cycle helmets reduces the severity of head injury to such an extent that dentists in primary care may be the first to see patients who have obvious dental trauma, no obvious head injury and yet may be suffering from signs of acute brain injury. They may also see patients for the treatment of dental trauma some hours after the patient has left the care of the Accident and Emergency Department (A\&tE). In both these circumstances it would be important for dentists to be in a position to accurately assess and refer or re-refer patients with suspected deterioration and signs of acute brain injury.

Despite an extensive literature search, no case histories or papers identifying problems in these areas have been identified. This does not necessarily imply that there is no problem; lack of awareness of a potential problem may result in a failure of identification and a failure to report. However, the importance of identifying individuals with a head injury cannot be underestimated as $17 \%$ of children ${ }^{1}$ and $15 \%$ of adults ${ }^{2}$ will have neurological stigmata associated with mild head injury. Dentists see many of their patients regularly and may be in a unique position to identify and refer patients with previously unidentified sequelae.

Also, in some District General Hospitals A\&tE departments, obvious dental trauma may mean that the Maxillofacial Senior House Officer (OMFS SHO) may be the clinician leading evaluation of the patient. In these circumstances the ability to accu- rately assess traumatic head and brain injury are essential, though these clinicians should have received ATLS (advanced trauma life support) training and should be capable of the correct assessment and management of such cases.

The publication, in June 2003, of the National Institute of Clinical Excellence (NICE) ${ }^{3}$ guidelines on the management of head injury made this an appropriate time to be raising these issues. These guidelines recognise the potential role of dentists in the referral of patients for further assessment and provide clinical algorithms for this purpose.

As the study was conceptualised, the 1997 edition of The first five years, published by the General Dental Council (GDC) ${ }^{4}$ was in force. Teaching relevant to head injury was covered by paragraphs 73-78 and stated that dentists should be capable of communicating with clinical colleagues (para 73) and able to deal with emergencies (para 75).

The second edition of The first five years ${ }^{5}$ is now in place. This version is much strengthened and requires the teaching of accident and emergency medicine (para 60, p 16; para 111, pp 27-28); the diagnosis and care of emergencies likely to occur in the dental surgery (para 61, pp 16-17) as well as the management of dental emergencies (para $90 \mathrm{p} \mathrm{24).}$ The teaching of the manifestations, investigation and treatment of human disease and pathology should use examples 'from all regions of the body' (para 54 and 55, p 15). Relevant topics are specified as "the maintenance of the well-being of patients, including the recognition of physical and mental illness ..." (para 57, p 16). Students are required to be "familiar with the main medical disorders that may impinge on dental treatment" (para 111, pp 27-28). The need to 
recognise the limitations of clinical skills and refer appropriately is emphasised (para 17, p 6) but no mention is made of head/brain injury.

Thus it may be seen that, although the second edition fails to mention head/brain injury, the scope and wording of the current guidelines could easily be modified/extended to include these areas. The results and recommendations set out below should be read in the context of the published guidance on the dental curriculum and the very specific recommendations set out in the NICE guidelines.

\section{METHOD}

Under the auspices of the registered charity, Headway - the brain injury association, a questionnaire covering the teaching of aetiology, epidemiology, presentation and clinical assessment and sequelae of acute head/brain injury was designed by the authors and sent to all 12 undergraduate dental schools in the UK. (The questions and responses appear in Tables $1 \mathrm{a}$ and $1 \mathrm{~b}$.) This was followed up by a second mailing, a telephone reminder and finally a third mailing if necessary.

\section{RESULTS}

The three mailings described above resulted in a $100 \%$ return rate. All the forms were completed, but with a varying amount of detail. The questions and responses are transcribed verbatim in Tables 1a and 1b. The original questionnaire contained a column requesting an estimate of the teaching time given to each area. This was impossible to complete as most of the areas were obviously covered in integrated teaching sessions. Any attempts to complete these details have been omitted from the results table.

It is gratifying to note that although no mention is made of head/brain injury in the current version of The first five years, 4,5 all dental schools already teach this subject.

The results worthy of highlight are:

- Of the 11 schools that teach the Glasgow Coma Scale (GCS), only one school, R (where the teaching is provided by a neurosurgeon) practised the skills of GCS assessment. School T specified that students shadowed an A\&tE SHO.

- Only at school R did the students practise GCS assessment on each other.

- Only four dental schools teach students about patients who 'talk and die' and/or diffuse axonal injury.

- The criteria for referral to hospital varied significantly, with schools V, W, X and Y giving very gross, non-specific criteria, falling short of the NICE criteria.

- From the information supplied, four schools $(0, R, S$ and $T)$ appeared to teach this area more thoroughly.

- Only schools O, S and Y mentioned CSF leaks as a diagnostic critera.

- The criteria taught for referral of head injury varied from the basic and inadequate, for example 'Step deformity and loss of consciousness' (Y) to the thorough $(\mathrm{O}, \mathrm{P}, \mathrm{R}$ and $\mathrm{S})$.

- The guidance taught to give to patients/carers varied considerably and was not comparable with the current NICE guidelines.

- Eight dental schools do not teach about the physical and psychological consequences of brain injury; Schools V and R teach about the physical consequences only.

- Nine dental schools teach nothing about the improvements patients can gain with rehabilitation. The response of School $\mathrm{P}$ is particularly disappointing.

\section{CONCLUSIONS AND DISCUSSION}

This study has the limitations of being based on a postal questionnaire. Its validity may also be reduced by the lack of explicit questions about ATLS. However, the results do indicate that the teaching of assessment of head injury to undergraduate dental students is patchy. Of the four apparently more thorough courses, teaching was undertaken by neurosurgeons at $\mathrm{O}$ and $\mathrm{R}$ and by a trauma surgeon at $\mathrm{S}$. The teaching staff at other schools were oral and maxillofacial surgeons (who are fully trained in this subject area) or unspecified. This suggests that teaching of this subject may benefit from specialist input or that OMFS input could be improved. External teaching staff may be less reliable due to other commitments, while OMFS staff are available on dental school staff. Also, no questions were asked about teaching of ATLS and it may be that if the questions had been couched in these terms, the responses may have differed.

Only at school R did the students practise assessing a GCS on each other. Other schools presumably hope that students will have an opportunity to undertake this assessment when on placement in outpatient clinics and ACtE or when shadowing an SHO. Thus, practice of the GCS is dependent on the 'luck of the draw'. This is a cause for concern because physical practice of such a skill, especially one which is likely to be used rarely in the future, is vital to learning and retaining the information and ability to undertake the assessment. 6

Although no specific question was asked (and should have been) about CSF leaks, only schools $0, \mathrm{~S}$ and $Y$ mentioned this sign. It is critical that dentists understand that any recent history of clear fluid running from the nose or ear could be due to a CSF leak and/or a cribriform plate/base of skull fracture and that 'nose bleeds' and bleeding from the ear can be a mixture of blood and CSF. ${ }^{7}$ CSF leak may be taught in OMFS trauma lectures and may therefore not have been mentioned in this context. Development of the undergraduate syllabus might include clarification as to which subject area has responsibility for teaching this point.

The responses from the dental schools raise concerns about the competence of newly qualified dentists taking up first posts as OMFS SHOs. In some District General Hospitals, patients with obvious oral/facial trauma and possible head injury are likely to be assessed by the OMFS SHO on call. General concerns about increasing the skills base of this group of clinicians have been expressed 8,9 and induction courses are being provided. Both the 'Dentist on the Ward' at Lincoln 10 and the Yorkshire Region course ${ }^{11}$ cover this 
Table 1a Summary of responses (Questions 1-4)

\begin{tabular}{|c|c|c|c|c|c|}
\hline & $\begin{array}{l}\text { Who teaches } \\
\text { the course? }\end{array}$ & $\begin{array}{l}01 \text { (Do your students receive } \\
\text { teaching in the aetiology } \\
\text { and epidemiology of head } \\
\text { injury? Please outline } \\
\text { subjects covered) }\end{array}$ & $\begin{array}{l}02 \text { (Do your students } \\
\text { receive teaching in the } \\
\text { physical presentation of } \\
\text { head injury? If yes, please } \\
\text { outline subjects covered) }\end{array}$ & $\begin{array}{l}03 \text { (Please describe the } \\
\text { signs and symptoms which } \\
\text { are taught as requiring hospital } \\
\text { assessment should a patient } \\
\text { with dental trauma visit a } \\
\text { dental surgery) }\end{array}$ & $\begin{array}{l}\text { 0 4. (Please describe the follow } \\
\text { up instructions your students } \\
\text { are taught to give to patients } \\
\text { if they suspect a head injury.) }\end{array}$ \\
\hline 0 & $\begin{array}{l}\text { Senior lecturer } \\
\text { neurosurgery }\end{array}$ & Yes & Yes & $\begin{array}{l}\text { In accordance with SIGN (Scottish } \\
\text { Intercollegiate Guideline } \\
\text { Network) guidelines }\end{array}$ & Sign Guidelines \\
\hline$P$ & Lecturer & Yes & Yes & $\begin{array}{l}\text { History of loss of consciousness } \\
+ \text { confusion, vomiting, change in } \\
\text { motor function } \\
\text { History of head injury - with } \\
\text { progressive symptoms headache, } \\
\text { vomiting, increasing lethargy or } \\
\text { irritation, reduced consciousness }\end{array}$ & $\begin{array}{l}\text { Not to be left alone at night. } \\
\text { To go to hospital or call for } \\
\text { help if has progressive } \\
\text { problems as } 03\end{array}$ \\
\hline 0 & OMFS & $\begin{array}{l}\text { Yes - RTA, interpersonal } \\
\text { violence, sport, fall, industrial }\end{array}$ & $\begin{array}{l}\text { Yes, only with concomitant } \\
\text { maxillofacial trauma.) } \\
\text { ATLS (advanced trauma life } \\
\text { support) }\end{array}$ & $\begin{array}{l}\text { Nausea, vomiting, deterioration } \\
\text { in neurological status }\end{array}$ & $\begin{array}{l}\text { Attend local accident and } \\
\text { emergency department }\end{array}$ \\
\hline$R$ & \begin{tabular}{|l} 
Consultant \\
neurosurgeon
\end{tabular} & Yes & Yes & $\begin{array}{l}\text { Increasing sleepiness, confusion, } \\
\text { consciousness, memory, papillary } \\
\text { reductions, response to stimulation, } \\
\text { rising blood pressure, slowing pulse }\end{array}$ & $\begin{array}{l}\text { 1. Check vital signs, heart rate, } \\
\text { blood pressure, breathing } \\
\text { 2. Clinical examination to } \\
\text { assess signs/symptoms } \\
\text { 3. Classify head injury } \\
\text { 4. Management according } \\
\text { to classification }\end{array}$ \\
\hline $\mathrm{s}$ & $\begin{array}{l}\text { Consultant } \\
\text { trauma surgeon }\end{array}$ & Yes & $\begin{array}{l}\text { Yes. Loss of consciousness, } \\
\text { confusion, amnesia, drowsy, } \\
\text { disorientated, does not respond } \\
\text { rationally to questions and } \\
\text { requests. Poor reaction of pupils to } \\
\text { light. Pupils fixed and dilated. } \\
\text { Limb reflexes reduced. Vomiting. }\end{array}$ & $\begin{array}{l}\text { Loss of consciousness. } \\
\text { State of pupils. Active } \\
\text { movement of limbs. } \\
\text { Heart rate/respiratory rate. } \\
\text { Amnesia. Vomiting }\end{array}$ & $\begin{array}{l}\text { Students are taught to refer } \\
\text { immediately to hospital if } \\
\text { a head injury is suspected. } \\
\text { I do not believe dentists have } \\
\text { the competence to manage } \\
\text { head injuries in general dental } \\
\text { practice. }\end{array}$ \\
\hline $\mathrm{T}$ & $\begin{array}{l}\text { Maxillofacial } \\
\text { surgeons }\end{array}$ & Yes & $\begin{array}{l}\text { Yes. As part of medicine/surgery/ } \\
\text { neurology teaching. Intra-cranial } \\
\text { and intra-cerebral bleeding. }\end{array}$ & $\begin{array}{l}\text { Deterioration in consciousness. } \\
\text { GCS score } \\
\text { Skull fractures } \\
\text { Amnesia }\end{array}$ & $\begin{array}{l}\text { Decrease in consciousness level } \\
\text { Headache, vomiting, return } \\
\text { to A\&E asap }\end{array}$ \\
\hline $\mathrm{U}$ & Not answered & Yes & $\begin{array}{l}\text { Focus on MFU injuries } \\
\text {-ABC - ATLS } \\
\text { Head injury in detail is a post grad } \\
\text { subject }\end{array}$ & One hour lecture & $\begin{array}{l}\text { They refer any trauma patient } \\
\text { if seen in practice. Low } \\
\text { threshold }\end{array}$ \\
\hline v & $\begin{array}{l}\text { Consultant } \\
\text { ActE Medicine) }\end{array}$ & Yes & $\begin{array}{l}\text { Yes - Awareness that brain injury is } \\
\text { likely if sufficient force applied to } \\
\text { give maxillo-facial trauma }\end{array}$ & $\begin{array}{l}\text { Change in consciousness level } \\
\text { with time }\end{array}$ & $\begin{array}{l}\text { Speak to accompanying person } \\
\text { If seen in A\&tE give head injury } \\
\text { sheet } \\
\text { Look for change in level of } \\
\text { consciousness - irritability, } \\
\text { vomiting }\end{array}$ \\
\hline w & Varies & Yes & $\begin{array}{l}\text { [Taught about head injury] As part } \\
\text { of one hour lecture. } \\
\text { Physical presentation taught only if } \\
\text { see such a patient in OMFS clinic }\end{array}$ & $\begin{array}{l}\text { Suspicion of jaw fracture. } \\
\text { Uncontrollable bleeding }\end{array}$ & None \\
\hline$x$ & $\begin{array}{l}\text { OMFS \& AEtE } \\
\text { placement) }\end{array}$ & No & Yes & Vomiting [and two illegible criteria] & As per A\&tE card \\
\hline$Y$ & Oral surgeon & Yes & Yes - CSF leaks & $\begin{array}{l}\text { Loss of consciousness } \\
\text { Step deformity }\end{array}$ & Glasgow coma \\
\hline $\mathrm{z}$ & OMFS & Yes & $\begin{array}{l}\text { Yes - signs of head injury, } \\
\text { complications and management and } \\
\text { specifically in relation to middle } \\
\text { third fracture. }\end{array}$ & $\begin{array}{l}\text { Patients attending a dental surgery } \\
\text { with dental trauma have localised } \\
\text { mid-face injury. Those with extensive } \\
\text { cranial injuries are seen in hospital } \\
\text { practice by appropriate specialists }\end{array}$ & Refer to A\&tE \\
\hline
\end{tabular}


Table 16 Summary of Responses (Questions 5-10)

\begin{tabular}{|c|c|c|c|c|c|c|}
\hline & $\begin{array}{l}\text { Q } 5 \text { (Are your students } \\
\text { taught a formal } \\
\text { method of assessing } \\
\text { consciouness eg the } \\
\text { Glasgow Coma Score } \\
\text { (GCS)? If yes, are they } \\
\text { given the opportunity } \\
\text { to practice on each } \\
\text { other?) }\end{array}$ & $\begin{array}{l}\text { 06 (Are your students } \\
\text { taught about the } \\
\text { patients who 'talk } \\
\text { and die' following } \\
\text { diffuse head injury?) }\end{array}$ & $\begin{array}{l}07 \text { (Which physical } \\
\text { effects of head } \\
\text { injury eg sub-dural } \\
\text { haematoma are your } \\
\text { students taught about?) }\end{array}$ & $\begin{array}{l}\text { 0 8 (Are your } \\
\text { students taught about } \\
\text { the mechanisms } \\
\text { of traumatic } \\
\text { brain injury?) }\end{array}$ & $\begin{array}{l}\text { 09. (Are your students } \\
\text { taught about the } \\
\text { physical and } \\
\text { psychological } \\
\text { consequences of } \\
\text { traumatic brain injury?) }\end{array}$ & $\begin{array}{l}\text { Q } 10 \text { (Do you teach } \\
\text { your students about } \\
\text { the improvements } \\
\text { which can be } \\
\text { achieved with } \\
\text { rehabilitation?) }\end{array}$ \\
\hline 0 & $\begin{array}{l}\text { Glasgow Coma Score. } \\
\text { No Practice }\end{array}$ & $\begin{array}{l}\text { Avoidable deaths and } \\
\text { secondary [illegible] } \\
\text { but not specifically } \\
\text { talk and die. }\end{array}$ & $\begin{array}{l}\text { Skull Fracture } \\
\text { Base of Skull fracture+l- } \\
\text { CSF leak } \\
\text { EDH [epidural haematoma] } \\
\text { SDH [subdural haematoma] } \\
\text { Contusions } \\
\text { DAI [Diffuse Axonal Injury] }\end{array}$ & $\begin{array}{l}\text { Microscopic - no } \\
\text { Macroscopic - yes }\end{array}$ & In outline only & Not specifically \\
\hline$P$ & No & $\begin{array}{l}\text { Not in any detail - only } \\
\text { that it occurs }\end{array}$ & - & $\begin{array}{l}\text { Microscopic - no } \\
\text { Macroscopic - yes }\end{array}$ & No & $\begin{array}{l}\text { No - they are dental } \\
\text { students not } \\
\text { postgrad surgeons. } \\
\text { When do they face } \\
\text { this problem? What is } \\
\text { the magnitude of the } \\
\text { problem ie cases } \\
\text { presenting to } \\
\text { dentistry as a first } \\
\text { port of call? }\end{array}$ \\
\hline 0 & $\begin{array}{l}\text { Glasgow Coma Score } \\
\text { Do not practice these } \\
\text { skills }\end{array}$ & No & $\begin{array}{l}\text { Closed/open head injury. } \\
\text { Very little detail }\end{array}$ & No & No & No \\
\hline$R$ & $\begin{array}{l}\text { GCS } \\
\text { Yes, practice }\end{array}$ & $\begin{array}{l}\text { Yes, detailed coverage } \\
\text { of consequences of } \\
\text { head injury }\end{array}$ & $\begin{array}{l}\text { Concussion, cerebral } \\
\text { contusions, lacerations, } \\
\text { intracranial haematomas, } \\
\text { epidural haematoma, } \\
\text { subdural haematoma, } \\
\text { specific lobe damage }\end{array}$ & $\begin{array}{l}\text { Microscopic - Yes } \\
\text { consequences of intra } \\
\text {-cranial pressure } \\
\text { Macroscopic - Yes } \\
\text { contracoup injury, } \\
\text { coning }\end{array}$ & $\begin{array}{l}\text { Yes - lost functions, } \\
\text { localised symptoms, } \\
\text { persistent or chronic } \\
\text { vegetative state, post } \\
\text {-traumatic epilepsy, } \\
\text { aphasia }\end{array}$ & Yes \\
\hline$S$ & $\begin{array}{l}\text { GCS No practice on } \\
\text { each other. }\end{array}$ & Yes & $\begin{array}{l}\text { Injuries to head, skull } \\
\text { fratures, injuries to the } \\
\text { brain, the unconscious } \\
\text { patient, haemorrhage } \\
\text { within the skull, CSF } \\
\text { leakage, definition of death }\end{array}$ & Yes & Yes & $\begin{array}{l}\text { Mentioned as part } \\
\text { of lecture }\end{array}$ \\
\hline $\mathrm{T}$ & $\begin{array}{l}\text { GCS. No practice on } \\
\text { each other but they } \\
\text { will shadow the resident } \\
\text { SHO attending A\&E }\end{array}$ & Yes & $\begin{array}{l}\text { Change in: consciousness } \\
\text { level, headache, GCS score, } \\
\text { personality, eyesight; fundal } \\
\text { changes; vomiting, fitting, } \\
\text { paralysis,sensory [loss], } \\
\text { memory (MTS) reduction }\end{array}$ & $\begin{array}{l}\text { Microscopic - no } \\
\text { Macroscopic - Yes }\end{array}$ & Probably no & No \\
\hline U & $\begin{array}{l}\text { Comment is made to } \\
\text { GCS + ATLS. No } \\
\text { practical skill. }\end{array}$ & No & In principle re pathology & $\begin{array}{l}\text { No, not to my } \\
\text { knowledge }\end{array}$ & $\begin{array}{l}\text { No, not to my } \\
\text { knowledge }\end{array}$ & $\begin{array}{l}\text { No, not to my } \\
\text { knowledge }\end{array}$ \\
\hline $\mathrm{V}$ & $\begin{array}{l}\text { AVPU scoring for } \\
\text { casualty assessment. } \\
\text { GCS only for coordination } \\
\text { with other medical } \\
\text { colleagues. }\end{array}$ & No & $\begin{array}{l}\text { Awareness of potential } \\
\text { intra-cranial bleed. } \\
\text { Specifics are not covered }\end{array}$ & No & $\begin{array}{l}\text { Physical - Yes } \\
\text { Part of the course deals } \\
\text { with management of } \\
\text { patients with disabilities } \\
\text { - physical, visual and } \\
\text { auditory are covered as } \\
\text { needed for access to dental } \\
\text { care. This section is to be } \\
\text { expanded in clinical } \\
\text { teaching in the future }\end{array}$ & No \\
\hline $\mathrm{W}$ & $\begin{array}{l}\text { GCS. } \\
\text { No practice }\end{array}$ & No & $\begin{array}{l}\text { Sub-dural } \\
\text { Extra-dural } \\
\text { Intra-cerebral } \\
\text { Depressed fractures }\end{array}$ & No & No, not specifically & No \\
\hline$x$ & GCS & No & $\begin{array}{l}\text { Not known, but may be } \\
\text { covered in Human Diseases } \\
\text { course }\end{array}$ & $\begin{array}{l}\text { Microscopic - No } \\
\text { Macroscopic - Yes }\end{array}$ & No & No \\
\hline $\mathrm{Y}$ & $\begin{array}{l}\text { GCS } \\
\text { No practice }\end{array}$ & No & [not answered] & No & No & No \\
\hline Z & $\begin{array}{l}\text { Yes } \\
\text { [Doesn't specify if } \\
\text { students practice.] }\end{array}$ & No & $\begin{array}{l}\text { Delayed onset of headache } \\
\text { and neck stiffness }\end{array}$ & None & None & $\begin{array}{l}\text { They are taught } \\
\text { about the effects of } \\
\text { rehabilitation with } \\
\text { other causes of head } \\
\text { injury }\end{array}$ \\
\hline
\end{tabular}


area and it is presumed that induction courses run by NHS Trusts also cover this as part of ATLS training, including use of the GCS.

Question 6, regarding patients who 'talk and die, was badly worded and thus may have been problematic for respondents and affected response levels. 'Talk and die' usually refers to extra-dural haemorrhage, but patients may also deteriorate significantly, though less spectacularly, as a result of diffuse axonal injury. These head injuries, which dentists are most likely to come across in general practice, are barely taught.

We believe it is crucial that dentists understand the nature of these conditions and how to assess them so that they can promptly refer to an appropriate centre. (This survey had no intention of suggesting that dentists attempt to manage head injury in dental practice, as suggested by school P.) The publication of the NICE guidelines $(2003)^{3}$ recognises that dentists have a vital role to play in the recognition of such patients.

It is extremely disappointing that so little is taught about the physical and psychological consequences of brain injury or the improvements that may come with time and active rehabilitation, though teaching of this area as part of the neurological aspects of human disease may have resulted in under-reporting. Setting the obvious sequelae of brain injury such as hemiplegia, aphasia and deafness to one side, many patients who have sustained even a mild head injury can have consequent and 'hidden' problems such as:

- chronic depression, fatigue and headaches

- increased irritability

- poor concentration

- an inability to tolerate noise,

all of which may make the acceptance of dental treatment difficult. ${ }^{7}$ These patients may also lack the insight to recognise that they have these problems or may choose to deny them and their disability. Many of these 'hidden' problems improve with time. Unfortunately, there are very few trained neuropsychologists in the UK, so patients with milder brain injuries are unlikely to have been able to access such an assessment and be unaware of some of their problems. It is therefore essential for dentists to have a basic understanding of likely recovery so as to be able to liaise with rehabilitation staff if they are involved or, if they are not, dentists should be able to make educated prognostic judgements in order to undertake longer-term dental treatment planning.

The NICE guidelines on the assessment and management of head injury ${ }^{3}$ were published in June 2003. This clearly sets out the following criteria:

- Indications for initial hospital referral by hospital advice services, for example NHS Direct;

- Indication for hospital referral by community health services and NHS minor injuries units (including general practice, NHS walk-in centres and dental practitioners);
- Criteria for A\&tE departments with regard to clinical and imaging assessment and admission criteria;

- Texts for patient and carer information and discharge sheets.

These guidelines would form an excellent basis for the teaching of this curriculum area.

(The NICE guidelines are available to download at www.nice.org.uk/pdf/cg4/niceguideline.pdf. The clinical algorithm designed for use in dental practice is available at www.nice.org.uk/pdf/cg4/nicealgorithm 2.pdf. Dental practitioners might also like to consider algorithm 1 (www.nice.org.uk/pdf/cg4/nicealgorithm 1.pdf) for use by reception staff after appropriate training.)

In conclusion, it is recommended that:

1. Dental schools in the UK review their teaching of head and brain injury in the light of this article and the NICE guidelines. This would be in line with the current edition of The first five years. ${ }^{5}$ Curriculum Enhancement - 'The GDC strongly supports measures taken by dental schools to enhance and develop dental curricula.' (para 134 p 37)

2. The GDC considers incorporating specific teaching of head and brain injury in the third edition of The first five years in the sections covering human disease and pathology and the management of medical and dental emergencies. This area of the syllabus could be designed to match the NICE guidelines and updated in parallel with the guideline reviews.

3. A follow up survey is carried out in approximately three years to evaluate any changes to syllabi.

1. Ponsford J, Willmott C, Rothwell A, Cameron P, et al. Cognitive and behavioural outcome following mild traumatic head injury in children. J Head Trauma Rehabil 1999: 14: 30-72.

2. Emanuelson I, Andersson Holmkvist E, Bjorklund R, Stalhammar D. Quality of life and post-concussion symptoms in adults after mild traumatic brain injury: a population study in western Sweden. Acta Neurol Scand 2003; 108: 332-338

3. National Institute of Clinical Excellence. Head injury - Triage, assessment, investigation and early management of head injury in infants, children and adults. London: National Institute of Clinical Excellence, 2003.

4. General Dental Council. The first five years - the undergraduate dental curriculum. London: General Dental Council, 1997.

5. General Dental Council. The first five years - A framework for undergraduate dental education. London: General Dental Council, 2002.

6. Kolb D A. Experiential learning - Experience as the source of learning and development. pp 39-60. New Jersey: Prentice Hall Inc, 1984.

7. Lindsay K W, Bone I, Callander R. Neurology and neurosurgery illustrated. 3rd ed. pp 214-235. Edinburgh \& London: Churchil Livingstone, 1997.

8. Standing Committee on Postgraduate Medical and Dental Education (SCOPME) Good practice in SHO training. London, 1991.

9. Standing Committee on Postgraduate Medical and Dental Education (SCOPME) A good start: Job induction for hospital doctors and dentists in training. London, 1993.

10. www.dentist-on-the-ward.co.uk accessed 24 Jan 2004

11. Stark P, Mitchell D A. Bridging the gap - Vocational trainee to senior house officer: a new induction course. Br Dent J 2003; 194: 167-171.
"We believe

it is crucial

that dentists

understand

the nature

of these

conditions

and how to

assess them

so that they

can promptly

refer to an

appropriate

centre" 